\title{
DIFFERENT GENERATIONS AND THE MANAGEMENT OF THEIR CAREERS: IMPORTANCE AND POTENTIALITY
}

\author{
DIFERENTES GERAÇÓES E A GESTÃO DE SUAS CARREIRAS: IMPORTÂNCIA E \\ POTENCIALIDADE
}

\section{Daniela Siqueira Colet}

Universidade de Passo Fundo, Passo Fundo, RS, Brasil, danicolet@hotmail.com

\section{Anelise Rebelato Mozzato}

Universidade de Passo Fundo, Passo Fundo, RS, Brasil, anerebe@upf.br

\section{Andrea Oltramari}

Universidade Federal do Rio Grande do Sul, Porto Alegre, RS, Brasil, andreaoltr@gmail.com

\begin{abstract}
This paper proposes a debate about the importance of multi-generational conviviality on organizations and the potentiality of career management to attract and retain different generations. The presence of different generations on the work environment consists on an immutable reality. Differences between people always existed and team work, mainly when there is no integration and a propitious environment, independently of generational differences, make the environment proper to the eclosion of conflicts. The conflicts do not have to be necessarily destructive, the divergence of opinion might be beneficial for employees and organizations, as long as there is an appropriate management. Therefore, by means of politics and practices of people management it becomes necessary the awareness towards generations, attracting and retaining them, aiming for a good conviviality between the different generations. Career management practices may allow insertion, the good conviviality, and the retention different generations on the labor market.
\end{abstract}

Keywords: multi-generational dynamics; careers management; work relationships.

Resumo: Este artigo propóe um debate sobre a importância da convivência multigeracional sobre as organizações e a potencialidade da gestáo de carreira para atrair e reter diferentes geraçóes. A presença de diferentes geraçóes no ambiente de trabalho consiste em uma realidade imutável. As diferenças entre as pessoas sempre existiram e o trabalho em equipe, principalmente quando não há integração e um ambiente propício, independentemente de diferenças geracionais, torna o ambiente propício à geração de conflitos. Os conflitos não precisam ser necessariamente destrutivos, a divergência de opinião pode ser benéfica para funcionários e organizaçóes, desde que haja um gerenciamento apropriado. Portanto, por meio de políticas e práticas de gestão de pessoas, torna-se necessária a conscientização para as geraçóes, atraindo-as e retendo-as, visando um bom convívio entre as diferentes gerações. As práticas de gestão de carreira podem permitir a inserção, o bom convívio e a retenção de diferentes geraçôes no mercado de trabalho.

Palavras-chave: dinâmica multigeracional; gestão de carreiras; relaçōes de trabalho. 


\section{Introduction}

In contemporary times, researches about generations had gain emphasis in the study on the field of people management and work relationships when considering the reality of the multi-managing dynamics as difficulties and potentialities to the organizations (SMOLA; SUTTON, 2002; HUNTLEY, 2006; CENNAMO; GARDNER, 2008; BENSON; BROWN, 2011; CAVAZOTTE; LEMOS; VIANA, 2012; GARDINER; GRACE; KING, 2013; PRITCHARD; WHITING, 2014; YI, et al.; 2015).

Each generation brings to organizations a different set of expectations, necessities, values and skills; provides different world views and attitudes in connection with compromise, flexibility, learning, entrepreneurship and, effectively, in general working (LYONS; KURON, 2013; WAAL; PETERS; BROEKHUIZEN, 2017). As Lyons and Kuron (2013) says, the new careers literature proposes that career mobility patterns are becoming more diverse, in addition to stating the need for more research on the subject.

Therefore, it becomes necessary a more holistic and interdisciplinary view of the multi-managing dynamics that constitute the work strength in the organizations (CULPIN; MILLAR; PETERS, 2015). Such view also becomes necessary due to the undeniable differences of classes, income, skin color, gender, and finally, social-economical-cultural matters associated to all generations.

The generational differences for many times are highlighted as tension creators in organizations, mainly by differences related to age (PRITCHARD; WHITING, 2014), peculiar features (CENNAMO; GARDNER, 2008; BENSON; BROWN, 2011; GARDINER; GRACE; KING, 2013) and different perceptions about career and professional growth (MANNHEIM, 1993). To Mannheim (1993), such differences happen because of historical events and shared experiences by each generational group.

When living together in the same work environment, different generations can strengthen the productivity and contribute to the organizational learning through shared experiences and knowledge. In this context, so organizations can attract and retain employees of different generations, it becomes vital to develop strategies that aim for the conviviality of groups of different ages in the same work environment. Therefore, the insertion and continuity of young employees are as important as the inclusion and permanence of older employees in the labor market (DENCKER; JOSHI; MARTOCCHIO, 2007; STEVES, 2010; BENSON; BROWN, 2011).

In this sense, one of the strategies to attract and retain different generations is to adopt career planning, as it tends to have a positive effect on employees' perception of their professional growth possibilities. Such plan can be on the framework of what is understood of organizational career as well as to think about individual careers. In these terms, it is important to mention that was on the 1980's that the associations between individual and organizational careers started, with Granrose and Portwood (1987). In this study, they postulate that, if there is no satisfaction with the career on the individual sense, there won't be an outcome on the organizational plan, meaning that, even if the organization structure a sophisticated career plan, little results will be achieved if the employees are not committed and motivated on staying in the organization.

The staying of different generations in organizations also concern the management of possible conflicts, in order to make the organizational environment a good place to develop labor activities, 
allowing a good conviviality between employees. In this line, Culpin, Millar and Peters (2015) argue about the necessity and relevance of the interdisciplinary research. Their argument is that the impact of the multi-managing is one of the critical problems that organizations will experience in the next five to ten years. Therefore, the academic literature needs to keep up with this tendency.

Based on the above considerations, this paper proposes a debate about the importance of multigenerational conviviality on organizations and the potentiality of career management to attract and retain different generations.

After this introduction, this paper contemplates a theoretical reference, approaching, on a first moment, the generational diversity, proceeding to dialogues between career management and generational diversity. Moving forward, career and generational diversity are worked: What is the possible critic? Finally, final considerations are presented with the intention of instigating the debate about this field of study.

\section{Generational diversity}

The debate about diversity has gained projection in organizations, in academic world and in society. The diversity refers to a variation of cultural and social identity between people living together a work environment and its components consist on race, gender, culture, nationality, disabilities, age and religion (NKOMO; COX JR, 1999). The generational diversity, the focus of this paper, is getting distinction in studies on this field of people management and work relationships (CENNAMO; GARDNER, 2008; BENSON; BROWN, 2011; CAVAZOTTE; LEMOS; VIANA, 2012; GARDINER; GRACE; KING, 2013; PRITCHARD; WHITING, 2014; CULPIN; MILLAR; PETERS, 2015; RUSSELL et al., 2016).

A generation can be understood as a part of the historical process that individuals of the same age share, the potentiality of witnessing the same events, live experiences, and process these events or experiences on a similar way (MANNHEIM, 1993). For this author, a generation consists on an important analytical dimension for the comprehension of the dynamics of social changes and ways of thinking and acting from a time. All these factors can deeply influence values, attitudes and beliefs of one generation.

On the other hand, Oliveira, Piccinini and Bitencourt (2012) demonstrate that different youths diverge on the sharing of events, even being the same age. This happens because they live through different events, having different perceptions and experiences about the same phenomenon. Therefore, it is important to make a contextualization of which characteristics and historical landmarks have contributed for the formation of youth's line of thought in each country.

The comprehension of the historical period allows to deepen possibilities and limitations that are presented to a group, starting by the economic, social and cultural conjuncture lived by it, allowing the deepening of this discussion about the chronological time that defines a generation, its relations towards other generations and its common experiences (OLIVEIRA; PICCININI; BITENCOURT, 2012).

The theories about generations make explicit that people born in a same period share historical and social experiences of life. Such common events can affect in a similar way the pattern of reacting towards situations and institutions, like values and beliefs about organizations; it also affects work ethics and the reasons why people work for, as well as objectives and aspirations in professional life. Therefore, it affects the behavior of people at work (SMOLA; SUTTON, 2002). 
It should be highlighted that the characteristics not necessarily must be strictly shared by all individuals born on the same period, there are similarities, as well as differences, not being possible to make any generalization, not even a framework of people in a given generation. It must be considered the culture, the historical events, the social, educational and economic differences that each individual is going through (OLIVEIRA; PICCININI; BITENCOURT, 2012).

Often, in work relationships, older employees fell bothered and, to a certain degree, threatened by younger ones. At the same time, younger employees must be sufficiently authentic towards their way of being and acting. Such situation might make the divergences more explicit. Between these divergences, it can be found the ones caused by the diversity promoted by variations of opinions, behaviors, ways of seeing and executing the job and the worldview of different generations (VELOSO, 2012).

In these terms, the different generations on the labor market generate challenges for the field of people managing regarding, mainly, to revising the politics, processes and practices of managing that aim for the interaction of groups of different generations in the organizations. Thus, practices that facilitate the entry of young people in the labor market become necessary, although on the one hand, there are propositions of programs for retirement or even for the continuity of older people on the labor market (DENCKER; JOSHI; MARTOCCHIO, 2007; BENSON; BROWN, 2011). In other words, the market could and should be opened to generational diversity. A well thought career strategy in organizations constitutes a possibility of meeting different expectations.

According to a study conducted by the Society of Human Resource Management (SHRM) (2011) in 2008 , there were $67,7 \%$ of people in the world aging between 25 and 54 years. It has been predicted that this rate will decrease to $63,5 \%$ until 2018 and the rate of people aging more than 55 years will increase from $18,1 \%$ in 2008 to $23,9 \%$ in 2018 . This data demonstrates that, increasingly, the labor strength will be characterized by the intergenerational work relationships.

Although there is a lot to debate and consolidate theoretically, researchers on this field agree that there are younger and older generations coexisting on the work environment: baby boomer (born between 1946 and 1967), generation X (born between 1968 and 1979), generation Y (born between 1980 and 1994) (SMOLA; SUTTON, 2002; CENNAMO; GARDNER, 2008; WAAL; PETERS; BROEKHUIZEN, 2017). More recently a younger generation, called generation $Z$, is also entering the labor market (COLET; MOZZATO, 2019). It is evidenced that authors diverge on the years of birth that divide these generations, therefore, any attempt of pointing the period referring to a generation is always approximate, being considered only as a guideline.

Veloso (2012) demonstrates that many studies conducted on Brazil point to the perception of generation Y about the work environment, always in aspects related to career. The results of conducted researches had shown that this generation feels optimistic about their possibilities of professional growth in the company where they work at only when they believe that the organizational environment creates a personal meaning and provides learning, development and possibilities of identification with the job. The author states that the perception of generation $\mathrm{Y}$ also distinguish from others by a higher strength on the impact of the possibility of obtaining balance between work and personal life, also about the sensation of affective commitment with the company where they work at. 
The research conducted by Cavazotte, Lemos and Viana (2012) reveals that there are more in common between the generation $\mathrm{Y}$ and its predecessors than what nonacademic literature would have considered. For the authors, work safety, tangible rewards as salaries and benefits appear as important, motivational and valued elements by young people, approaching them from older generations.

The research also offers support to a notion of young employees stablishing psychological contracts that favor pleasure, liberty and social involvement. At the same time, it indicates that the new seems to coexist with the traditional, since contemporary expectations combine to wishes common to older generations, reinforcing the perception that there are expectations towards the subsisting job, despite objective changes on the productive sphere (CAVAZOTTE; LEMOS; VIANA, 2012).

Complementarily, according to a research conducted by Colet and Mozzato (2019), it is revealed that one of the main contributions of generation $\mathrm{Z}$ to organizations is the ability with new technologies; however, the biggest difficulty is in managing this generation, due to its immediacy and necessity of fast career growth. According to the authors, regarding to strategies for the management of this generation, it was pointed by managers the importance of accompaniment and dialogue between different generations and, also, the thinking of a differentiated career plan to attract and maintain these employees the longest possible in the company.

On that logic, the organizational context is composed by different generations that have distinct perspectives, characteristics and behaviors. It is known that differences might trigger conflict situations. On the other hand, when these differences are managed, they can lead to a diversity of ideas, dynamism and active posture for the construction of new managing models, solutions, as well as other contributions favoring the organizational performance (STEVES, 2010).

Waal, Peters and Broekhuizen (2017) say of the importance of managers to consider the various points of view of different generations (psychological traits), thus improving cooperation between them and, consequently, organizational performance. In this sense, Twenge, Campbell (2008) point out that organizations must be ready to deal with differences, especially psychological ones. Joshi, et al. (2010) argue that such differences impact each other's expectations, which is no different in relation to professional careers.

It is understood that multi-generational dynamics, more than generating conflicts, create needs on different generations, instigating the conviviality, taking knowledge from memories and learning new things. Moreover, to enjoy sharing knowledge and experiences. Still, the conviviality between employees of different generations, exactly because of the diversity of characteristics, may strengthen the creativity and productivity at work (SILVA; DUTRA; VELOSO, 2014).

The presence of different generations at the work environment is beneficial, also consisting in an immutable reality. Organizations themselves must identify the characteristics and behaviors of each generation, for, that way, valuing the individual potentials in accordance to individual, collective and organizational well-being (COLET; MOZZATO, 2019). As these authors have stated, this constitutes on a challenge for the field of people management in terms of the necessity of reviewing the precept of work relationships. 
According to a study conducted by Silva, Dutra and Veloso (2014), generation Y presents generational characteristics that propel people management to propose working structures that are able to provide activities that generate learning, pleasure, self-realization, and the conciliation of work and personal life. Such structures are important for all workers, regardless the generations these belong to.

More and more technology is among the most recent generations technological advancement, globalization, and environmental change impact thinking about the future of careers (HALL YIP; DOIRON, 2018). However, current theologized generations are comfortable with these trends and, as the authors state, they are aware of the need to seek new skills and new ways of working. The new technological standards have transformed the way people manage the various spheres of their lives, including work, with new forms (HAEGER; LINGHAM, 2014).

According to the research carried out by Dante and Arroyo (2017), all generations demonstrate a clear tendency towards the career anchor: lifestyle. Regardless of the generation, the word "personal" presents a phenomenon of genuine search for intimate realization, more than achieving financial success, power, hierarchical growth or even challenge and new knowledge acquisition.

Therefore, for organizations to retain talents of different generations, Steves (2010) alerts that it becomes vital to develop strategies that conduct to a multi-generational dynamics workforce, considering the existing diversity between generations on the work environment. The social influence of the generations is directly related to their careers, paths taken in their lives according to their needs, expectations and visions. Each generation presents different histories, cultures and possibly perspectives and interests, which would present the need to analyze them, for a greater understanding of people managers as to how to carry out their initiatives, to conceive organizational movements, succession, knowledge and work, in search of harmony of careers and organizations (DANTE; ARROYO, 2017).

On this logic, aiming for contributions from the multi-generational conviviality for organizations, the career planning might constitute into an important strategy for the attraction and retaining of different generations in the work environment. When thinking about career planning, it is important to mention what has been researched on professional insertion and career construction.

\section{Ways of career construction, challenges of retaining people and generation}

To think about different generations and their wish of staying in an organization or not, it also concerns dialoguing the generations subject with career management. Therefore, people can advance on their careers both in individual and organizational levels. For example, organizational careers is to be understood as the effort that an specific organization executes to provide support to the employees, when considering professional capacitation and development, promotions and a career plan supporting its human resources politics (BARUCH, 2004, 2006).

By offering employees not only a salary, but also structured careers, aiming to keep them attracted and retained, is one of the functions of organizational careers. The different levels or steps offered by the organization, say much about staying motivated. The organizational careers orientate a person to different perspectives, powers, rights, privileges, identity, also guiding the performance evaluation, executed by others, on this person (GLASER, 2010). 
Additionally, some theoretical questions about career have been pointing to investing on the rationality of decision-making (DUTRA, 2010). That means rationally organizing the employee's promotion, in the case of taking careers in these terms.

That way, Dutra (2010) suggests building within the organizations a succession map. For this author, a succession map should be an indicating instrument to execute the succession. At the point of start of one succession process, it should be pondered the situation specificity and the indication of the best person for that position, at that moment, not always being the one who is in first place in priority order at the succession map (DUTRA, 2010).

On the succession map, according to Dutra (2010), important information can be found about the effectiveness of what was proposed, especially by knowing the people considered able or in conditions of being prepared primarily by the level of preparation or by profile for the position. However, there is still a great amount of underutilized people in the organizations, generally marginalized both from promotions and development actions from the company. Therefore, a succession map can also assist, on a rational way, on the resolution of possible conflicts between generations, when considering their career development.

Even that nowadays some studies argue about the notion of a career being predominantly individual, others also present the importance of the structure of an organizational career plan (BARUCH, 2006; DUTRA, 2010). In general, organizations have an organizational structure, with its hierarchical definitions, even if not in a total concreteness.

The organizational structures are associated to the career plan structures. In general, there is a variation on career plans and its structures. A parallel career, for example, set parameters so the employee can choose between a technical or a managing professional development. This way, this career structure contributes for the maintenance of the employee on the technical field, if this is chosen, avoiding this way, having to be on the management area to grow financially, having neither the profile nor the vocation for such function.

The other possibility of choice between career structures is the one in Y. This one is also characterized by the possibility of choice, made by the employee, between technical and managing careers. What differentiates it from the parallel structure is that choice is made after some time. In other words, the action basis is given primarily on general areas, offering support for future decisions, according to the trajectory followed in the company. It is also possible to highlight the careers with multiple parallelisms, having as a characteristic the possibility of multiple choices of presenting professional trajectories, being them: technical, managing, researching or administrative (DUTRA, 2010).

This way, it is important to think about different career structures, for different generations. Depending on the generation and professional qualifications, for example, people wishes will be different, and not meeting them might cause underutilizing of personnel (RUSSELL et al, 2016). That being exemplified, an employee on the beginning of the adult life, and another one ageing approximately 50 years, can diverge on the objectives of their professional lives, desires and qualifications when taking different positions, being these a leadership, a supportive or a technical function. As a suggestion, Russell et al. (2016) state that some strategies might be used with the objective of retaining people: job rotation, mentoring activities and informal leadership incentives. 
Besides that, the existence of people close of retiring should also be a subject to think over about a career plan, embracing the desires of people on that phase. Retirement can be seen as a transition of the professional status, as a change on the trajectory that was been followed. Associated to these aspects, retirement brings with itself the ageing issue, which justifies the necessity of preparing the employee for the moment of his job dismissal. A career plan should be accompanied by a retirement plan. For Camarano (2001) if retirement is not well planned, it can play, on a certain way, the role of expulsion from the labor market.

From the point of view of organizational careers, the contracts established between employees and company also predict opportunities of professional development, especially for those who have adjusted to the offered position. On the other hand, it can be presumed that these also strongly invested on their individual careers, such as the protean career (HALL, 1996).

The protean career demands constant investments on new and different areas of expertise. Briscoe and Hall (2006) elaborated some profiles that employees must have based on the combination of boundary less and protean careers, such as: making solid decisions, being idealists and questioners. According to these authors, such profiles allow an effective intervention on conducting personnel's careers.

Thus, individual careers are associated to the investment that an individual makes on professional life, what has been entitled by some authors as career self-management (FONTENELLE, 2005; OLTRAMARI; GRISCI, 2013). Other studies are also associated to individual career, such as researches about boundary less careers and kaleidoscopic career (MAINIERO; SULLIVAN, 2005).

In this sense, it is considered a challenge for organizations to concretize a plan that can both fulfill different generation's wishes and ensure an organizational and financial structure capable of attending management opportunities. The opportunities are to provide a long professional life to the talents inside organizations where they work at, even coming from different generations.

Santos (2015) states about the perception of success that younger and older employees have. To the author, younger employees have a bigger necessity of success coming with their career growth, differently from an older one. It is, therefore, clear that the success in the career also can be considered a subjective element on its construction, as some authors have pondered (EATON; BAILYN, 2000). On the results obtained, Santos (2015) described that the necessity of life quality and the search for a greater balance between family and work happens to everyone, independently of the generation they belong to.

According to a research conducted by Lyons et al. (2012), younger generations change jobs and employers on a higher rate than older generations and are more eager to accept not only moving on the career vertically. Recruiting and retaining younger employees, thus, require a different approach than the one used on older generations. Three years later, the research pointed that significant differences were observed on professional and organizational mobility of numerous generations, being the younger ones more mobile than the others (LYONS; SCHWEITZER; NG, 2015).

Therefore, due to the lack of clear career plans, evaluation and remuneration, some of the young employees with great potential and the wish of growing inside the company find themselves discouraged for not having a perspective of career growth or means of raising their salaries. 
A career plan that contemplates on its rules and criteria the acceptance of work construction through creativity is also essential. Vertical careers plan that, besides of requirements and rules for professional ascension, also contemplate the opening of autonomy and liberty on decision-making and work construction. According to Dejours (2004), to work implies the involvement of the body, mobilization of intelligence, the capacity of reflection, interpreting, and reacting towards situations, and this mobilization of intelligence becomes evident when the employee feels satisfied by realizing both the social utility of his work and the possibilities created by his development. The job, on this case, demonstrates as essentially social, once it both influences society when performed and is influenced by this one through sensorial and affective experiences.

The only moment that an individual has the freedom of escaping the predetermination of execution is on inappropriate moments for the main activity execution, when the time is utilized to perform other tasks with lower technical content. According to Dejours (2004), for a job to be performed, it is necessary the adjustment of the prescription and the tuning of effective work organizing, which is different from the prescribed organizing. By the moment the employee uses non useful time from his technical competence for adverse activities, although related to his function, he is adjusting the prescription and making a kind of effective organizing.

When a job is highly prescribed and do not predict an opening for creativity, it might cause the necessity of high level of cooperation and coordination by the employees, aiming to safely perform the task. Dejours (2004) states that for the work process to work, it is necessary to readjust the prescription, transforming coordination into cooperation. That being said, it seems to be important a career plan that also contemplates cooperation between work colleagues, embracing the generational differences. Therefore, it is important to mention that different generations need, regardless of age, creative jobs, where they can freely use their creativity.

It is worth discussing a little about youth and ageing, to explicit moments of life, as well as passages of life experienced during life. Some questions about this issue (getting old) become necessary: the retirement does not represent anymore the disconnection of the professional world, but a thought about other careers, other activities. In that way, some questions emerge, such as: Are people going to be healthy enough for that? Are people going to be respected by younger ones? That being said, it is necessary to think that generational differences go beyond thinking of a career structure, in addition to other possibilities that involve tolerance, group work, conviviality, and aspects related to work conditions.

The lifetime of everyone is considerably longer. What paths will be found on the field of work relations and people management, to resolve these questions? Until when will people endure building up their careers? Are they going to be healthy enough for that? Therefore, it becomes important to think about the role of the field of people management providing life quality to the work environment (GOWAN, 2014).

Some researchers are already worried with this. A study conducted by Cepellos, Tonelli, and Aranha Filho (2013) about the ageing of workforce demonstrates that at present, companies report preferences on hiring always younger employees, especially because of the belief that older employees will be more expensive, slower, more accommodated, as some selectors have stated. 
Common sense, myth and untruths being perpetuated on the field of people management end up making work relationships precarious. How do they become precarious? When career plans are constructed, for example, bringing difficulties to the growth of older people within the company, it is prioritized the hiring and training of only younger people. It is the older ones that most of the times can suffer the loss of their jobs and career detours, as stated by Gowan (2014). The author calls the attention towards healthcare and life quality, parallel to career care.

On the other hand, there are also the latent desires of youth. Have being said that the concepts of youth are multiple, it becomes necessary to think that organizations need to think different career structures to embrace different desires and histories from different youths, considering generation diversity.

Russell et al. (2016) state about different qualifications obtained by employees and the role of career structures to embrace them. The greatest qualification cannot become a problem to both organization and employees. Therefore, when a career opportunity is offered, the most qualified employees will be able to fill these and, with that, bigger responsibilities will come. Accordingly, it is also possible to make a reflection about different generations and how they adequate the company's necessities. Different generations, in this case, should strongly invest in professional qualification, new skills and get ready to transfer knowledge. For the authors, the biggest qualification and a career plan that contemplates it also promotes a bigger individual and organizational commitment. As stated by Hall, Yip and Doiron (2018), more and more the generations work well with these tendencies that involve the technology, being conscious and being able to the necessity of the qualification for such.

To Malhotra and Singh (2016) the skill of building a network is also essential to adjust the best employees to the career plan. For the authors, employees with a higher potential should be assisted by managers to grow inside the organization. Regardless to the generation they belong to, they should exercise both the learnings of team's mentors and coaches.

Apart from this, the issue of gender and balance between career and family should also be an exercise about generational diversity and career. Regardless the generation, the challenge of building up a career and at the same time caring about family relationships is present on everyone's life. To recognize both women and men at the labor market and to balance their responsibilities is everyone's task. The pressure that comes from the family is sensed by the employees, both men and women. Studies are showing that women suffer both from family pressure and biological clock, determined by the different phases on their lives (TANURE; CARVALHO NETO; ANDRADE, 2007; TREMBLAY, 2005).

The study conducted by Tremblay (2005), in special, suggests that measures should be taken by the company in order to create a balance between both work and family. However, it was noticed a low implementation of such measures, despite what is said by human resources managers and syndicate leaders worried with this issue. The author requested to three hundred Canadian organizations to choose what benefits they were wishing to achieve. The most cited ones were benefits projected to support the balance on work and family relationships, in special involving career politics that were able to comprehend the progression of both men and women.

Just as Tremblay (2005) and Sullivan and Mainiero (2007) state about the actions to retain women in career plans that contemplate their personal and professional lives. For the authors, regardless the women's age, their desires and investments will modify in relation with their career development. 
Depending on the situation, they will perform career interruptions, and possibly reduce the professional commitment if their choice is to invest on personal life.

Therefore, different generations have characteristics and behaviors that are related to the social context and the historical moment in which they live, learn and relate. Given this, it can be seen that it is possible to have a career plan that meets the different generations, as long as they include remuneration, benefits, progression trails, performance evaluation, training and development, among others. In this way, the possibility of meeting the expectations of workers of different generations in relation to personal fulfillment, balance between personal and professional life, professional valorization, job security and opportunities and challenges is expanded. Finally, it is up to organizations to identify what their workers want, how to attract them, develop them and maintain them.

\section{Final remarks}

To attract and retain good workers that are able to aggregate value and are dedicated on fulfilling objectives is being a constant challenge to organizations. This dialogue represents an effort to evince the importance of the multi-generational conviviality in organizations and potentialities of career management for the attraction and retention of different generations.

To think the potentiality of career planning also concerns investing on processes that companies institute to encourage the employee to invest on a career, such as: performance evaluation, employees' potential evaluation, capabilities, succession plans and programs of management based on competency (BOHLANDER; SNELL; SHERMAN, 2003; BARUCH; 2006). It is believed that investing on people management practices, coupled to a broad career plan, which contemplates the diverse and different necessities and desires of generations (from youths), both organizations and individuals from work will be able to be successful.

It is evidenced that the presence of different generations on the work environment consists on an immutable reality. Differences between people always existed and team work, mainly when there is no integration and a propitious environment, independently of generational differences, make the environment proper to the eclosion of conflicts. The conflicts do not have to be necessarily destructive, the divergence of opinion might be beneficial for employees and organizations, as long as there is an appropriate management. Therefore, by means of politics and practices of people management it becomes necessary the awareness towards generations, attracting and retaining them, aiming for a good conviviality between the different generations.

When thinking about practical strategies considering career management, it is important to have as support basis the people management. For so, this field of study might imply into what is referred as a database about its workers such as informations about: age; intentions, personal and professional mobility; dilemmas and desires about familiar life; available time dedicated to work, studies and career; expectations on progressing and desires related to management or technic positions; and development of individual specific competencies for the position and area of work. Therefore, this dialogue expects to contribute especially to the evolution of the generations' theme, which has been pointed as emergent in 
people management in an international context, configuring as a relevant subject, with a broad space in academic researches (BENSON; BROWN, 2011).

From the practical point of view, it is believed that this dialogue and systematic review of the literature will provide benefits from the reflections here proposed for professionals of people management. On this hand, the research will bring contributions to the academy and also to organizations, on the context of elaborating and implementing strategies to the practices of people management. Most of all, practices of career management that might allow the insertion, the good conviviality, and the retaining of different generation on the labor market.

\section{References}

BARUCH, Y. Career development in organizations and beyond: balancing traditional and contemporary viewpoints. Human Resource Management Review, v. 16, n. 2, p. 125-138, 2006.

BARUCH, Y. Transforming careers: from linear to multidirectional career paths. Career Development International, v. 9, n. 1, p. 58-73, 2004.

BENSON, J; BROWN, M. Generations at work: are there differences and do they matter? The International Journal of Human Resource Management, v. 22, n. 9, p.1843-1865, 2011.

BOHLANDER, G; SNELL, S; SHERMAN, A. Administração de recursos humanos. São Paulo: Pioneira Thomson Learning, 2003.

BRISCOE, J. P.; HALL, D.T. The interplay of boundary less and protean careers: combinations and implications. Journal of Vocational Behavior. v. 69, n. 1, p. 4-18, 2006.

CAMARANO, A. A. O Idoso Brasileiro no Mercado de Trabalho. $5^{\circ}$ Congresso Nacional de Estudios del Trabajo, Buenos Aires, 2001. Anais (online). Buenos Aires, ASET. Available in: <https:// www.aset.org.ar/congresos/5/aset/PDF/Camarano.PDF>. Accessed in: nov 2020.

CAVAZOTTE, F.S; LEMOS, A. H; VIANA, M. D. A. Novas geraçôes no mercado de trabalho: expectativas renovadas ou antigos ideais? Cadernos EBAPE.BR, v. 10, n. 1, p. 162-180, 2012.

CEPELLOS, V. M; TONELLI, M. J; ARANHA FILHO, F. Envelhecimento nas Organizaçôes: Percepçôes e Práticas de RH no Brasil, In: Anais do Encontro Nacional dos Programas de PósGraduação em Administração. Brasília. Anais... Brasília: ENGPR, 2013.

CENNAMO, L; GARDNER, D. Generational differences in work values, outcomes and personorganization values fit. Journal of Managerial Psychology, v. 23, n. 8, p. 891-906, 2008.

COLET, D.C; MOZZATO, A. R. "Nativos digitais": características atribuídas por gestores à Geração Z. Desenvolve, v.8, n.2, 2019.

CULPIN, V; MILLAR, V; PETERS, K. Multi-generational frames of reference: managerial challenges of four social generations in the organization. Journal of Managerial Psychology, v. 30, n. 1, 2015. 
DANTE, F. S.; ARROYO, R. F. Âncoras de carreira: por onde caminham as geraçóes? Revista de Carreiras e Pessoas, v. VII, n.02, Mai/Jun/Jul/Ago. 2017

DEJOURS, C. Subjetividade, trabalho e ação. Revista Produçáo, v. 14, n. 3, p. 27-34, 2004.

DENCKER, J. C; JOSHI, A; MARTOCCHIO, J. J. Employee benefits as context for intergenerational conflict. Human Resource Management Review, v. 17, n. 2, p. 208-220, 2007.

DUTRA, J. Gestáo de Carreiras nas empresas contemporânea. São Paulo: Atlas, 2010.

EATON, S. C.; BAILYN, L. Career as Life Path: Tracing Work and Life Strategies of Biotech Professionals.” In Career Frontiers: New Conceptions of Working Lives, edited by Maury Peiperl, Michael Arthur, Rob Goffee, and Tim Morris, pp. 177-98. Oxford, England: Oxford University Press, 2000 .

FONTENELLE, I. A. Eu Proteu: A auto-gestão de carreira entre fatos e mitos. In: Encontro Da Associação Nacional De Pós-Graduação Em Administração, 29. 2005, Brasília. Anais... Rio de Janeiro: ANPAD, 2005.

GARDINER, S.; GRACE, D.; KING, C. Challenging the use of generational segmentation through understanding self-identity. Marketing Intelligence \& Planning, v. 31, n. 6, p. 639-653, 2013.

GOWAN, M. A. Moving from job loss to career management: The past, present, and future of involuntary job loss research. Human Resource Management Review, v. 24, n.3, 2014.

GLASER, B. Organizational Career: a forward theory. Grounded Theory Review, v. 3, n. 9, 2010.

GRANROSE, C; PORTWOOD, J. Matching individual career plans and organizational career management, In: Academy of Management Journal, v. 30, n. 4, p. 699-720, 1987.

HAEGER, D. L; LINGHAM, T. A trend toward work life fusion: a multi-generational shift in technology use at work. Technological Forecasting and Social Change, v. 89, n. 9, p. 316-325, 2014.

HALL, D. Protean careers of the 21st century. Academy of Management Executive, v. 10, n. 4, p. 8-16, 1996.

HALL, D. T; YIP, J; DOIRON, K. Protean career at work: self-direction and values orientation in psychological success. Annual Review of Organizational Psychology and Organizational Behavior, v. 5, n. 6, p.1- 6, 2018.

HUNTLEY, R. The world according to Y: Inside the new Adult Generation. Allen and Unwin, Sydney, p. 228, 2006.

JOSHI, A; DENCKER, J. C; FRANZ, G; MARTOCCHIO, J. J. Unpacking generational identities in Organizations. Academy of Management Review, v. 35, n. 3, p. $392-414,2010$.

LYONS, S; KURON, L. Generational differences in the workplace: a review of the evidence and directions for future research. Journal of Organizational Behavior, v .35, n. 1, p. 139-157, 2013. 
LYONS, S. T; SCHWEITZER, L; EDDY S. W; KURON, L. K. Comparing apples to apples: A qualitative investigation of career mobility patterns across four generations. Career Development International, v. 17, n. 4, p. $333-357,2012$.

LYONS, S. T; SCHWEITZER, L; NG, E. S. How have careers changed? An investigation of changing career patterns across four generations. Journal of Managerial Psychology, v. 30, n. 1, p. 8 - 21, 2015.

MAINIERO, L; SULLIVAN, S. Kaleidoscope careers: an alternative explanation for the opt-out revolution. Academy of Management Executive, v. 19, n. 1, p. 106-123, 2005.

MANNHEIM, K. El problema de las generaciones. Revista Española de Investigaciones Sociológicas, n. 62, p.145-168, 1993.

MALHOTRA, P; SINGH, M. Indirect Impact of high performers on the career advancement of their subordinates. Human Resource Management Review, article in press, 2016.

NKOMO, S. M; COX JR, T. Diversidade e identidade nas organizaçóes, In: Clegg, SR, Hardy, C. and Nord, WR. Handbook de estudos organizacionais: modelos de análise e novas questóes em estudos organizacionais. São Paulo: Atlas, pp. 334-360, 1999.

OLIVEIRA, S. R; PICCININI, V. C; BITENCOURT, B. M. Juventudes, gerações e trabalho: é possível falar em geração y no Brasil? Revista Organizaçóes e Sociedade, v. 19, n. 62, p. 551-558, 2012.

OLTRAMARI, A; GRISCI, C. L. Dilemmas and Career Development of Brazilian Bank Executives. African Journal of Business Management, v. 7, p, 1161-1173, 2013.

PRITCHARD, K; WHITING, R. Baby Boomers and the Lost Generation: On the Discursive Construction of Generations at Work. Organization Studies, v. 35, n. 11, p. 1605-1626, 2014.

RUSSELL, Z. A; FERRIS, G. R; THOMPSON, K.W; SIKORA, D. M. Overqualified human resources, career development experiences, and work outcomes: leveraging and underutilized resources with political skill. Human Resource Management Review, v. 26, n. 2, p.125-135, 2016.

SANTOS, G. G. Career barriers influencing career success: A focus on academics' perceptions and experiences. Career Development International, v.21, n.1, 60-84. 2015

SILVA, R. C.; DUTRA, J. S.; VELOSO, E. O conhecimento e a experiência em sobreposição à idade: a Gestão das geraçôes de uma organização industrial. Revista Gestão Contemporânea, Porto Alegre, n. 15 , p. 254-277, 2014.

SMOLA, K.W. SUTTON, C. D. Generational Differences: revisiting generational work values for the new millennium. Journal of Organizational Behavior. v. 23, p. 363-382, 2002.

STEVES, R. H. Managing human capital: how to use knowledge management to transfer knowledge in today's multi-generational workforce. International Business Research, v. 3, n. 3, p. 77-83, 2010. 
SULLIVAN, S; MAINIERO, L. Kaleidoscope Careers: Benchmarking Ideas for fostering FamilyFriendly workplaces. Organizational Dynamics, v. 36, n. 1, p. 45-62, 2007.

TANURE, B; CARVALHO NETO, A; ANDRADE, J. Executivos: sucesso e (in) felicidade. Rio de Janeiro: Elsevier, 2007.

TREMBLAY, D. Gerentes e a conciliação entre trabalho e família, In: Davel, Eduardo; Mello, MC (Orgs.). Gerência em açáo: singularidades e dilemas do trabalho gerencial. São Paulo: Ed. FGV, 2005.

TWENGE, J. M; CAMPBELL, S. M. Generational differences in psychological traits and their impact on the workplace. Journal of Managerial Psychology, v. 23 n. 8, p. 862-877, 2008.

VELOSO, E. F. É possível negar a existência da geração Y no Brasil? Organizaçáo e Sociedade, v. 19, n. 62, p. 745-747, 2012.

WAAL, A; PETERS, L; BROEKHUIZEN, M. Do different generations look differently at high performance organizations? Journal of Strategy and Management, v. 10, n. 1, p. 86-101, 2017.

YI, X.; RIBBENS, B.; FU, L.; CHENG, W. Variation in career and workplace attitudes by generation, gender, and culture differences in career perceptions in the United States and China. Employee Relations, v. 37, n. 1, p. 66-82, 2015. 